\title{
19: 50565669-50546686
}

National Cancer Institute

\section{Source}

National Cancer Institute. 19: 50565669-50546686. NCI Thesaurus. Code C42208.

Physical location of ERCC2_Gene 